\title{
A search for mycoplasma infections in patients with chronic bronchitis
}

\author{
J. D. CHERR Y ${ }^{1}$, D. T A Y L OR - R O B I NSON, H. WILLER S ${ }^{2}$, \\ and A. C. STENHOUSE \\ Clinical Research Centre, Harvard Hospital, Salisbury, Wilts, and the University of Sheffield, \\ Virus Research Laboratory, Lodge Moor Hospital, Sheffield
}

\begin{abstract}
Throat and bronchoscopy specimens for mycoplasma isolation studies were collected from 22 patients with chronic bronchitis and 20 patients without chronic bronchitis. Twenty-six of 50 patients attending a chronic bronchitis clinic had throat, nasal, or sputum specimens collected for attempted mycoplasma isolation, and all of these patients had multiple serum samples taken for mycoplasma antibody studies. Mycoplasmas were recovered from throat and bronchoscopy specimens of the chronic bronchitic and non-bronchitic patients with about equal frequency. The concentration of organisms in the bronchoscopy specimens of two patients with chronic bronchitis was greater than in their throat specimens, suggesting downward spread and multiplication of mycoplasmas rather than contamination by passage of the bronchoscope. Eighty-three per cent of the rises in mycoplasma antibody titre in chronic bronchitic patients occurred during or immediately after an acute respiratory illness, and this relationship of rise in antibody titre to acute illness was significantly more frequent than rises in antibody titre not associated with illness. We suggest that mycoplasmas may be present in the bronchi of some patients suffering from chronic bronchitis and that, while such mycoplasma infections are often silent, they may become sufficiently active during infection by other agents to stimulate a mycoplasma antibody response.
\end{abstract}

Mycoplasmas in animals are frequently involved in chronic illnesses. In particular, Mycoplasma gallisepticum is one of the agents responsible for chronic respiratory disease of chickens (Fabricant, 1969 ) and $M$. pulmonis, while probably not having a primary aetiological rôle, is certainly involved in the murine chronic respiratory syndrome (Tully, 1969). Because these animal illnesses are somewhat similar to chronic bronchitis in man we thought that a mycoplasma might have some rôle in the human disease. The present study is a search for mycoplasma infections in patients with chronic bronchitis and in subjects without this disease.

\section{MATERIALS AND METHODS}

PATIENT POPUlation Two groups of patients were studied. Group 1 comprised 42 adults who underwent

IVisiting worker in Salisbury from the Department of Pediatrics, St. Louis University School of Medicine, St. Louis, Mo. 2Visiting worker in Salisbury in receipt of a WHO junior research training grant. Permanent address: Staatliches Medizinaluntersuchungsamt, 3 Hannover, Auestrasse 30, West Germany therapeutic and/or investigative bronchoscopy io Sheffield during September and October 1965. Oळ these persons, 22 had chronic bronchitis and the remaining 20 without chronic bronchitis served as control group. Group 2 consisted of 50 patients wh attended the bronchitis clinic of the Royal Hospitah Sheffield during the period July 1964 to July 1965 Multiple serum samples were collected from these patients at times of quiescence and during exacerba tions of respiratory illness. Of this group, 26 patients also had swabs taken on one or more occasion front. the throat and nose, or sputum collected for attempted mycoplasma isolation; specimens were collected dur? ing periods of both quiescence and exacerbation of clinical illness.

COLLECTION OF SPECIMENS Throat swabs (cottonwool) were obtained from group 1 bronchoscopt patients after the sucking of a benzocaine lozenge Prilocaine anaesthetic was then sprayed in the mouth and larynx and bronchoscopy was performed. Bronchial aspirate was collected directly into screw-cappe\& vials or into sterile U-tube side arms of a suction apparatus. When difficulty in clearing thick aspirafe was encountered, clearance was effected using sterit phosphate-buffered saline. 
Specimens were collected in duplicate and placed in bottles which contained $4 \mathrm{ml}$ of mycoplasma liquid medium. Single specimens from group 2 patients were also placed in mycoplasma liquid medium contained in bottles. All specimens were kept at $4^{\circ} \mathrm{C}$ immediately after collection, were transported to Salisbury at $-70^{\circ} \mathrm{C}$, and stored at this temperature until laboratory investigations were performed during May to December 1969.

ISOLATION OF MYCOPLASMAS The medium used for the culture of mycoplasmas has been described previously (Manchee and Taylor-Robinson, 1968). Frozen specimens were thawed at $37^{\circ} \mathrm{C}$ and then $0.1 \mathrm{ml}$ of each was inoculated on agar medium $(\mathrm{pH}$ $7 \cdot 8$ ) and $0.2 \mathrm{ml}$ aliquots of each were inoculated into $1.8 \mathrm{ml}$ of liquid medium contained in screwcapped vials of $2.5 \mathrm{ml}$ capacity. The liquid medium was supplemented with $0.1 \%$ of either glucose, arginine, or $\mathrm{l}$ ea. Cultures were incubated at $37^{\circ} \mathrm{C}$, the agar media in an atmosphere of $5 \% \mathrm{CO}_{2}$ and $95 \% \mathrm{~N}_{2}$. Vials which contained media supplemented with arginine or urea were observed for two weeks and those with glucose for three weeks. If during these times a change of colour was observed in the media, they were subcultured into liquid media and onto agar medium. In addition, medium which contained arginine was routinely subcultured onto agar medium at 4 and 10 days of incubation.

Agar media were incubated for three weeks and observed at intervals for the development of colonies. Such colonies were cloned to agar medium and then grown in liquid medium containing arginine. Isolates from liquid medium cultures were cloned in agar and finally grown in liquid medium for identification.

IDENTIFICATION OF ISOLATES This was done by the disc growth-inhibition technique (Clyde, 1964). Rabbit antisera prepared against the following mycoplasmas were used: $M$. salivarium (strain PG20), $M$. orale type 1 (strain CH 19299), and M. hominis (strain V2785).

SEROLOGICAL STUDIES Antibody in the sera of group 2 patients was titrated by the metabolic-inhibition (MI) technique as described by Taylor-Robinson, Purcell, Wong, and Chanock (1966) and Purcell, Taylor-Robinson, Wong, and Chanock (1966). The following mycoplasmas were used: $M$. salivarium (strain SP425H), $M$. orale type 1 (strain CH 19299), $M$. hominis (strain SP425B), and $M$. pneumoniae (strain FH).

\section{RESULTS}

MYCOPLASMA ISOLATIONS One hundred and thirtythree specimens from 68 patients in groups 1 and 2 were examined and 43 mycoplasma strains were recovered (Table $\mathrm{I}$ ). The majority of the strains were isolated from the throat (isolation rate $52 \%$ ).
T A B L E I

SOURCE AND TYPE OF MYCOPLASMAS ISOLATED

\begin{tabular}{|c|c|c|c|c|c|c|}
\hline \multirow[b]{2}{*}{ Source } & & \multirow{2}{*}{$\begin{array}{l}\text { No. of } \\
\text { Speci- } \\
\text { mens }\end{array}$} & \multicolumn{4}{|c|}{ Isolates } \\
\hline & & & Total & $\underset{\text { varium }}{\text { M. sali- }}$ & $\underset{\text { hominis }}{M .}$ & $\begin{array}{c}\text { M. orale } \\
\text { type } 1\end{array}$ \\
\hline $\begin{array}{ll}\text { Nose } & \ldots \\
\text { Throat }^{1} & \ldots \\
\text { Sputum } & \ldots \\
\text { Bronchoscopy }\end{array}$ & $\begin{array}{l}\cdots \\
\cdots \\
\cdots \\
\cdots\end{array}$ & $\begin{array}{l}18 \\
63 \\
10 \\
42\end{array}$ & $\begin{array}{r}2 \\
34 \\
2 \\
5\end{array}$ & $\begin{array}{r}2 \\
20 \\
2 \\
4\end{array}$ & 12 & $\begin{array}{l}2 \\
1\end{array}$ \\
\hline Total & $\ldots$ & 133 & 43 & 28 & 12 & 3 \\
\hline
\end{tabular}

${ }^{1}$ Both $M$. salivarium and $M$. hominis were found in one specimen from the throat.

Five strains were isolated from bronchoscopy specimens (isolation rate $12 \%$ ). Of the 43 strains isolated, 28 were $M$. salivarium, 12 were $M$. hominis, and 3 were $M$. orale type $1 ; M$. pneumoniae was not isolated.

The number of organisms present in each specimen containing mycoplasmas was assessed and is recorded in Table II. Sixty-two per cent of the specimens known to have mycoplasma organisms contained 10 or more colony-forming units (CFU) $/ 0 \cdot 1 \mathrm{ml}$.

Isolations from patients undergoing bronchoscopy (group 1) The source and type of mycoplasma isolated are recorded in Table III. Eleven myco-

T A B L E I I

CONCENTRATION OF MYCOPLASMA ORGANISMS IN 42 POSITIVE SPECIMENS

\begin{tabular}{|c|c|c|c|c|}
\hline \multirow[b]{2}{*}{ Source } & & \multicolumn{3}{|c|}{$\begin{array}{l}\text { No. of Specimens with Indicated No. of } \\
\text { Colonies } / 0.1 \mathrm{ml}\end{array}$} \\
\hline & & $<10$ & $10-100$ & $>100$ \\
\hline $\begin{array}{ll}\text { Nose } & \ldots \\
\text { Throat } \quad \ldots \\
\text { Sputum } \quad \ldots \\
\text { Bronchoscopy }\end{array}$ & $\begin{array}{l}\cdots \\
\cdots \\
\cdots\end{array}$ & $\begin{array}{c}1 \\
14^{1,2} \\
2\end{array}$ & $\begin{array}{l}1 \\
8^{2} \\
1 \\
3\end{array}$ & $\begin{array}{r}12 \\
1\end{array}$ \\
\hline
\end{tabular}

1 Includes two isolates that were recovered initially only in liquid medium containing $0 \cdot 1 \%$ arginine.

${ }^{2}$ One throat specimen contained mycoplasmas of two types.

\section{T A B L E I I I}

DISTRIBUTION OF MYCOPLASMAS IN 22 CHRONIC BRONCHITIC AND 20 NON-BRONCHITIC PATIENTS (BRONCHOSCOPY PATIENTS OF GROUP 1)

\begin{tabular}{|c|c|c|c|c|}
\hline \multirow{2}{*}{$\begin{array}{l}\text { Source and Type of } \\
\text { Mycoplasma Isolated }\end{array}$} & & & \multicolumn{2}{|c|}{ No. of Patients } \\
\hline & & & Bronchitic & Non-bronchitic \\
\hline 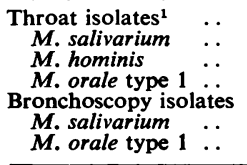 & $\begin{array}{l}\cdots \\
\cdots \\
\cdots \\
\cdots \\
\cdots\end{array}$ & $\begin{array}{l}\cdots \\
\cdots \\
\cdots \\
\cdots \\
\cdots \\
\cdots\end{array}$ & $\begin{array}{l}9 \\
9\end{array}$ & $\begin{array}{r}12 \\
8 \\
2 \\
2 \\
3 \\
2 \\
1 \\
\end{array}$ \\
\hline \multicolumn{3}{|c|}{$\begin{array}{l}\text { Total no. of mycoplasmas } \\
\text { isolated } \ldots\end{array}$} & 11 & 15 \\
\hline Total no. of patients ex & . & & 22 & 20 \\
\hline
\end{tabular}

1 Two organisms were recovered from one non-bronchitic patient. 
T A B L E I V FINDINGS IN FIVE PATIENTS WHOSE BRONCHOSCOPY SPECIMENS YIELDED MYCOPLASMAS

\begin{tabular}{|c|c|c|c|c|c|c|}
\hline \multirow[b]{2}{*}{ Patient No. } & \multirow[b]{2}{*}{ Source } & \multicolumn{2}{|c|}{ Mycoplasmas } & \multirow{2}{*}{$\begin{array}{c}\text { Polymorpho- } \\
\text { nuclear Cells } \\
\text { Seen on Smear } \\
\text { of Bronchial } \\
\text { Aspirate }\end{array}$} & \multirow{2}{*}{$\begin{array}{c}\text { Diplococcus } \\
\text { pneumoniae } \\
\text { on Routine Culture } \\
\text { of Bronchial } \\
\text { Aspirate }\end{array}$} & \multirow[b]{2}{*}{ Diagnosis } \\
\hline & & $\begin{array}{l}\text { Colonies } / 0 \cdot 1 \mathrm{ml} . \\
\text { of Specimen }\end{array}$ & Identification & & & \\
\hline 1 & $\begin{array}{l}\text { Throat } \\
\text { Bronchoscopy }\end{array}$ & $\begin{array}{l}73 \\
16\end{array}$ & $\begin{array}{l}\text { M. salivarium } \\
\text { M. salivarium }\end{array}$ & - & - & $\begin{array}{r}\text { Carcinoma } \\
\text { bronchus }\end{array}$ \\
\hline 2 & $\begin{array}{l}\text { Throat } \\
\text { Bronchoscopy }\end{array}$ & $\begin{array}{r}2 \\
14 \\
3\end{array}$ & $\begin{array}{l}M . \text { salivarium } \\
M . \text { hominis } \\
M . \text { orale type } 1\end{array}$ & - & - & $\begin{array}{r}\text { Carcinoma } \\
\text { bronchus }\end{array}$ \\
\hline 3 & $\begin{array}{l}\text { Throat } \\
\text { Bronchoscopy }\end{array}$ & $\begin{array}{r}96 \\
1\end{array}$ & $\begin{array}{l}\text { M. salivarium } \\
M . \text { salivarium }\end{array}$ & - & - & $\begin{array}{l}\text { Suspected carcinoma } \\
\text { - not confirmed }\end{array}$ \\
\hline 4 & $\begin{array}{l}\text { Throat } \\
\text { Bronchoscopy }\end{array}$ & $\begin{array}{r}3 \\
35\end{array}$ & $\begin{array}{l}\text { M. salivarium } \\
\text { M. salivarium }\end{array}$ & + & + & $\begin{array}{c}\text { Chronic } \\
\text { bronchitis }\end{array}$ \\
\hline 5 & $\begin{array}{l}\text { Throat } \\
\text { Bronchoscopy }\end{array}$ & $\begin{array}{r}2 \\
87\end{array}$ & $\begin{array}{l}\text { M. salivarium } \\
\text { M. salivarium }\end{array}$ & + & + & $\begin{array}{c}\text { Chronic } \\
\text { bronchitis }\end{array}$ \\
\hline
\end{tabular}

plasmas $(50 \%)$ were isolated from the chronic bronchitic patients and $15(75 \%)$ from the nonbronchitic subjects. The concentration of organisms in the throats of the subjects in each group was about the same. Further, mycoplasmas were isolated no more frequently from the bronchoscopy specimens of chronic bronchitic patients than from patients without bronchitis. All those patients who had a bronchoscopy specimen from which a mycoplasma was isolated also had the organisms in their throat specimens (Table IV).

\section{T A B L E V}

RELATIONSHIP OF CLINICAL STATUS OF 26 CHRONIC BRONCHITIC PATIENTS (GROUP 2) TO ISOLATION OF MYCOPLASMAS FROM THEM

\begin{tabular}{|c|c|c|c|}
\hline Source & & $\begin{array}{l}\text { Acute Respiratory } \\
\text { Illness (no. isolations/ } \\
\text { no. spec:mers) }\end{array}$ & $\begin{array}{c}\text { Quiescent Phase } \\
\text { (no. isolations/ } \\
\text { no. spec:mens) }\end{array}$ \\
\hline $\begin{array}{l}\text { Nose } \\
\text { Throat } \\
\text { Sputum }\end{array}$ & $\begin{array}{l}\ldots \\
\cdots \\
\cdots\end{array}$ & $\begin{array}{l}2 / 15 \\
7 / 14 \\
2 / 9\end{array}$ & $\begin{array}{l}0 / 4 \\
6 / 7 \\
0 / 1\end{array}$ \\
\hline Total & $\ldots$ & $11 / 38$ & $6 / 12$ \\
\hline
\end{tabular}

However, the concentration of organisms in the bronchoscopy specimens from the two patients with chronic bronchitis was greater than in the corresponding throat specimens, whereas the converse was the case for the non-bronchitic patients. It is of interest that in one non-bronchitic patient (No. 2) the type of mycoplasma isolated from the bronchoscopy specimen was different from the types recovered from the throat. In addition to a large number of mycoplasma organisms, both chronic bronchitic patients had polymorphonuclear cells in smears and pneumococci were recovered on culture of aspirated bronchial material whereas this was not so in the non-bronchitic patients.
Isolations from chronic bronchitic patients (group 2) Twenty-six patients in this group had one or more specimens submitted for attempted $\vec{\theta}$ mycoplasma isolation. Thirty-eight specimens were obtained during acute respiratory illnesses and 12 during quiescent periods. As noted in Table V, the majority of mycoplasmas were isolated from the throat specimens and isolations were more common during quiescence than during $\stackrel{\circ}{\circ}$ acute respiratory illness.

SEROLOGICAL STUdies The 50 patients in group 23 who suffered from chronic bronchitis each had two or more serum specimens submitted for mycoplasma antibody studies. A total of 205 sera were examined and, of these, 70 were obtained during episodes of acute respiratory illness and $\times$ 129 during quiescent periods (the clinical condition was not recorded at the time of collection of six specimens). The relationship of the rise in anti-

T A B L E V I

RELATIONSHIP OF RISE IN MYCOPLASMA ANTIBODY $D$ TITRE TO CLINICAL CONDITION OF CHRONICO

\begin{tabular}{|c|c|c|c|}
\hline \multirow[b]{2}{*}{$\begin{array}{l}\text { Mycoplasma } \\
\text { Used in Test }\end{array}$} & \multicolumn{3}{|c|}{$\begin{array}{l}\text { No. of Four-fold or Greater MI Antibody } \\
\text { Titre Rises }\end{array}$} \\
\hline & $\begin{array}{l}\text { After Acute } \\
\text { Respiratory } \\
\text { Illness }\end{array}$ & $\begin{array}{l}\text { Diring Acute } \\
\text { Respiratory } \\
\text { Illness }\end{array}$ & $\begin{array}{l}\text { Not Asso- } \\
\text { ciated with } \\
\text { Acute Respi- } \\
\text { ratory Illness }\end{array}$ \\
\hline $\begin{array}{l}\text { M. salivarium } \\
M . \text { hominis } \\
\text { M. orale type } 1 \\
\text { M. pneumoniae }\end{array}$ & $\begin{array}{l}2 \\
3 \\
1 \\
7\end{array}$ & $\begin{array}{l}4 \\
3 \\
1 \\
4\end{array}$ & $\begin{array}{l}1 \\
4\end{array}$ \\
\hline $\begin{array}{l}\text { Total no. rises } \\
\text { total no. } \\
\text { possible rises }\end{array}$ & $13 / 54(24 \%)$ & $12 / 45(27 \%)$ & $5 / 50(10 \%)^{2}$ \\
\hline
\end{tabular}

${ }^{1}$ Total no. of possible rises was calculated by observing the no. of clinical exacerbations during the time of serological study.

${ }_{2} \mathrm{P}<0.05$ when compared with the combined results of antibody rises noted after and during acute respiratory illness. 
body titre to the clinical condition of the patient is recorded in Table VI. Eighty-three per cent of the rises in antibody titre, as measured by the MI technique, occurred during or immediately after an episode of acute respiratory illness. The antibody titre rises in 'illness' and in 'non-illness' groups were compared with the total antibody titre rises that were possible in each group. When this was done, it was seen that the relationship of rise in antibody titre to illness was significantly more frequent $(P<0.05)$ than rises in antibody titre not associated with illness. On the other hand, there was no correlation between the rise in titre of antibody to a particular mycoplasma and the isolation of that mycoplasma from the patient. Furthermore, in many cases in which a mycoplasma was isolated antibody was not detected in the serum from the patient.

\section{DISCUSSION}

Chronic bronchitis is characterized clinically by chronic or recurrent productive cough as a result of chronic inflammation of the bronchial system. In addition to chronic respiratory symptoms, acute exacerbations of illness occur in which there is an increase in either the quantity or purulence of sputum. The excessive production of mucus is associated with hyperplasia of the mucous glands. The primary factor(s) which initiate(s) this change is obscure, although many aspects of the pathogenesis of the disease and its exacerbations are known. Acknowledged factors concerned in the progression of the disease include irritants in the inspired air, stagnation of mucus, inhibition of ciliary activity, and infection by various microorganisms (Chodosh and Segal, 1964; StuartHarris, 1968).

It has been shown (Sommerville, 1963 ; Carilli, Gohd, and Gordon, 1964 ; Stark, Heath, and Curwen, 1965 ; Eadie, Stott, and Grist, 1966 ; Ross, McMichael, Eadie, Lees, Murray, and Pinkerton, 1966 ; Stenhouse, 1967 ; Stott, Grist, and Eadie, 1968) that many virus infections can cause clinical exacerbations of chronic bronchitis and that Haemophilus influenzae and possibly Diplococcus pneumoniae are important in the chronic quiescent disease as well as in exacerbations (Hers, 1961 ; Lees and McNaught, 1959; Stuart-Harris, 1968).

Mycoplasmas might also play a role in chronic bronchitis in one or more of the following ways. First, mycoplasma infection could be the primary aetiological factor, the organisms being a constant irritant to the epithelium resulting in excessive mucus production. If this were the case, it could be postulated that other irritants, including bacteria, were secondary factors contributing more to the periodic exacerbations. A precedent for this hypothesis is found in chronic respiratory disease of chickens in which $M$. gallisepticum may cause a chronic infection of the respiratory tract which is made worse by secondary infection with viruses and bacteria (Fabricant, 1969). Secondly, mycoplasma infection of the human respiratory tract could be silent, the organisms not causing an effect by themselves. However, acute irritation by other factors such as viruses might cause activation to produce disease. If this were the case, a single mycoplasma infection could be related to the symptomatology of multiple exacerbations. A

T A B L E V I I

MYCOPLASMA STUDIES IN CHRONIC BRONCHITIS AND OTHER RESPIRATORY ILLNESSES

\begin{tabular}{|c|c|}
\hline Investigators & Findings \\
\hline $\begin{array}{l}\text { Morton, Smith and Keller (1952) } \\
\text { Carilli et al. (1964) }\end{array}$ & $\begin{array}{l}10 \text { bronchoscopy samples were examined and none yielded mycoplasmas } \\
4 \text { of } 46(8 \cdot 7 \%) \text { acute respiratory illnesses in chronic bronchitis patients were associated with } \\
\text { probable } M . \text { pneumoniae infection }\end{array}$ \\
\hline $\begin{array}{l}\text { Rytel, Conner, Welch, Kraybill, Edwards, } \\
\text { Rosenbaum, Frank, and Miller (1964) }\end{array}$ & $\begin{array}{l}173 \text { patients were bronchoscoped and } 45 \text { mycoplasma strains were isolated. These } \\
\text { comprised } 35 \text { from } 108 \text { bronchiectasis patients, } 6 \text { from } 42 \text { bronchopneumonia patients, } \\
2 \text { from } 7 \text { chronic bronchitic patients, and } 2 \text { from } 11 \text { patients with other pulmonary } \\
\text { conditions }\end{array}$ \\
\hline Ross et al. (1966) & No rises in titre of complement-fixing antibody to $M$. pneumoniae were noted in 125 \\
\hline Hers and Masurel (1967) & $\begin{array}{l}26 \text { exacerbations of chronic bronchitis and emphysema were associated with } \\
M \text {. pneumoniae infection }\end{array}$ \\
\hline Organick and Worman (1967) & $\begin{array}{l}78 \text { patients underwent bronchoscopy and mycoplasmas were isolated from } 11.5 \% \\
\text { and from pharyngeal swabs of } 33 \% \text {. Mycoplasmas were also recovered from the } \\
\text { pharynx of } 28 \text { of } 50 \text { normal subjects. They were not recovered from bronchoscopy } \\
\text { specimens of } 15 \text { patients with chronic bronchitis }\end{array}$ \\
\hline Lambert (1968) & $\begin{array}{l}\text { Complement-fixing antibody to } M \text {. pneumoniae was noted in } 16.4 \% \text { of } 566 \text { normal subjects } \\
\text { and in } 35 \% \text { of } 137 \text { chronic bronchitic patients }\end{array}$ \\
\hline Inglis, Davies and Andrews (1969) & $\begin{array}{l}100 \text { patients underwent bronchoscopy and mycoplasmas were recovered from } 25 \\
\text { pharyngeal swabs and } 8 \text { bronchoscopy specimens. The bronchoscopy-positive specimens } \\
\text { were from the following clinical categories: carcinoma, } 4 \text {; infective process, } 1 \text {; non- } \\
\text { infective process, } 1 \text {; unknown. } 2\end{array}$ \\
\hline
\end{tabular}


third possibility is that mycoplasmas have no great part in the long-term chronic bronchitis syndrome but that infection with a specific mycoplasma might be responsible for a particular exacerbation. This situation would seem to occur when chronic bronchitic patients are initially infected with $M$. pneumoniae. In Table VII a summary is presented of mycoplasma studies in chronic bronchitis and some other respiratory illnesses. The findings of Carilli et al. (1964) and Hers and Masurel (1967), as well as those of the present study, suggest that $M$. pneumoniae infection in a patient with chronic bronchitis is frequently associated with an acute clinical exacerbation. Whether other mycoplasma serotypes play a part in chronic bronchitis and its acute exacerbations is less clear. In the present study, as well as in those recorded in Table VII, there is no apparent meaningful relationship between the presence of mycoplasmas in throat or bronchoscopy specimens and the presence of chronic bronchitis or exacerbations thereof. Of course the low rate of isolation from bronchi may not be a true reflection of the presence of mycoplasmas. A single specimen taken at bronchoscopy is hardly likely to give a precise picture of the mycoplasma flora throughout the bronchial system. The low isolation rate is probably not the result of storing specimens at $-70^{\circ} \mathrm{C}$ for four years. The observations of Addey, Taylor-Robinson, and Dimic (1970) indicated that mycoplasmas survived for years at $-70^{\circ} \mathrm{C}$. Furthermore, the isolation rate of $52 \%$ from throat specimens in the present study is similar to that noted by Organick and Worman (1967), although the isolation rate for $M$. orale type 1 was lower than expected (Hendley and Jordan, 1968).

An interesting finding in the present study was that the mycoplasma organisms in bronchoscopy specimens taken from the chronic bronchitic patients were in a greater concentration than those in corresponding throat specimens. This suggests at least that the mycoplasmas found in the bronchial secretions spread from the throat to the bronchi and multiplied there and that their presence was not just the result of contamination of the lower respiratory tract by passage of the bronchoscope. The rises in the titre of antibody (Table VI) are also of interest. These rises were detected against mycoplasmas which were not always recoverable from the patient. This could be due to the inefficiency of mycoplasma isolation or to a lack of specificity of the MI technique. The latter is extremely specific for the measurement of antibody in rabbit antisera but less so with acute infection sera (Purcell, Wong, Chanock, Taylor-Robinson, Canchola, and Valdesuso, 1967). The results of many studies have shown that mycoplasmas may be isolated repeatedly from the oropharynx of persons without disease. $\stackrel{\otimes}{\Omega}$ They were recovered from the throat, nose, or sputum of more than $50 \%$ of all the patients we studied, including those without chronic bron- chitis. In view of the existence of such chronic $\vec{\omega}$ infection, it would not seem plausible that many of the rises of antibody titre were the result of acute infections by mycoplasmas. As myco-in plasmas of human origin other than $M .9$ pneumoniae have rarely, if ever, been found to be the cause of respiratory illness, it would be difficult to accept them as a primary cause of acute exacerbations in chronic bronchitis.

The facts at hand suggest that mycoplasmas may well be present in the bronchi of some patients suffering from chronic bronchitis for considerable periods of time; whether in $\operatorname{such}_{\vec{\omega}}$ cases they contribute to the pathogenesis of the $\triangle$ condition is difficult to say. However, the fact that 25 acute exacerbations of chronic bronchitis wereo associated with four-fold rises in the titre of mycoplasma antibody suggests that at these times the organisms of silent infections were suddenly $\frac{\mathrm{D}}{\mathrm{O}}$ more antigenic, possibly by more active participation in tissue damage. It could be postulated that $\overrightarrow{\overrightarrow{0}}$ these periods of increased mycoplasma activity 3 were the secondary result of infections with other agents such as viruses or bacteria. The work of Jordan and Kulasegaram (1968) tends to support this hypothesis. They noted that chickens chronic-을 ally infected by $M$. gallisepticum had rises in thex titre of antibody to this mycoplasma during acute $\frac{\sigma}{3}$ infections with infectious bronchitis virus. Furthermore, Reed (1971) has found an increased multiplication of $M$. hyorhinis in pig and calf tracheal organ cultures infected by swine influenza? virus.

We thank Pamela F. Clayton, Kathleen A. Keast, and Elizabeth M. Minton for technical assistance.

\section{REFERENCES}

Addey, J. P., Taylor-Robinson, D., and Dimic, M. (1970) Viability of mycoplasmas after storage in frozen of lyophilized states. J. med. Microbiol., 3, 137.

Carilli, A. D., Gohd, R. S., and Gordon, W. (1964). A® virologic study of chronic bronchitis. New Engl. J.+ Med., $270,123$.

Chodosh, S., and Segal, M. S. (1964). Chronic bronchitis. $\frac{}{(\mathbb{D}}$ New Engl. J. Med., $270,894$.

Clyde, W. A. Jr. (1964). Mycoplasma species identification based upon growth inhibition by specific antisera. $\frac{\varrho}{\sigma}$
J. Immunol., 92, 958 . 
Eadie, M. B., Stott, E. J., and Grist, N. R. (1966). Virological studies in chronic bronchitis. Brit. med. J., 2, 671.

Fabricant, J. (1969). Avian mycoplasmas. In The Mycoplasmatales and the L-phase of Bacteria. Edited by $\mathrm{L}$. Hayflick, p. 621. Appleton-Century-Crofts, New York.

Hendley, J. O. and Jordan, W. S. (1968). Mycoplasma pharyngeal flora in civilians. Amer. Rev. resp. Dis., 97, 524.

Hers, J. F. P. (1961). The pathology of chronic relapsing muco-purulent bronchitis, with and without bronchiectasis. In Bronchitis: An International Symposium, 1960, Univ. Groningen, edited by N. G. M. Orie and H. J. Sluiter, p. 149. Thomas, Springfield, Illinois.

- and Masurel, N. (1967). Infection with Mycoplasma pneumoniae in civilians in the Netherlands. Ann. N.Y. Acad. Sci., 143, 447.

Inglis, J. M., Davies, J., and Andrews, B. E. (1969). On the comparative mycoplasma flora of the upper and lower respiratory tract of man. In Mycoplasma Diseases of Man. Edited by M. Sprossig and W. Witzleb, p. 125. Gustav Fischer, Jena.

Jordan, F. T. W., and Kulasegaram, P. (1968). Latent infection of chickens and turkeys with Mycoplasma gallisepticum. Vet. Rec., 82, 655 .

Lambert, H. P. (1968). Antibody to Mycoplasma pneumoniae in normal subjects and in patients with chronic bronchitis. J. Hyg. (Lond.), 66, 185.

Lees, A. W., and McNaught, W. (1959). Bacteriology of lower-respiratory-tract secretions, sputum, and upperrespiratory-tract secretions in "normals" and chronic bronchitics. Lancet, 2, 1112.

Manchee, R. J., and Taylor-Robinson, D. (1968). Haemadsorption and haemagglutination by mycoplasmas. J. gen. Microbiol., 50, 465.

Morton, H. E., Smith, P. F., and Keller, R. (1952). Prevalence of pleuropneumonia-like organisms and the evaluation of media and methods for their isolation from clinical material. Amer. J. Publ. Hlth, 42, 913.

Organick, A. B., and Worman, L. W. (1967). Isolation and identification of mycoplasma from the lower respiratory tract in bronchoscopy patients. Amer. Rev. resp. Dis., 95, 618 .
Purcell, R. H., Taylor-Robinson, D., Wong, D. C., and Chanock, R. M. (1966). A color test for the measurement of antibody to the non-acid-forming human mycoplasma species. Amer. J. Epidem., 84, 51.

- Wong, D., Chanock, R. M., Taylor-Robinson, D., Canchola, J., and Valdesuso, J. (1967). Significance of antibody to mycoplasma as measured by metabolicinhibition techniques. Ann. N.Y. Acad. Sci., 143, 664.

Reed, S. E. (1971). The interaction of mycoplasmas and influenza viruses in tracheal organ cultures.J. infect. Dis., (submitted for publication).

Ross, C. A. C., McMichael, S., Eadie, M. B., Lees, A. W., Murray, E. A., and Pinkerton, I. (1966). Infective agents and chronic bronchitis. Thorax, 21, 461.

Rytel, M. W., Conner, G. H., Welch, C. C., Kraybill, W. H., Edwards, E. A., Rosenbaum, M. J., Frank, P. F., and Miller, L. F. (1964). Infectious agents associated with cylindrical bronchiectasis. Dis. Chest, 46, 23.

Sommerville, R. G. (1963). Respiratory syncytial virus in acute exacerbations of chronic bronchitis. Lancet, 2 , 1247.

Stark, J. E., Heath, R. B., and Curwen, M. P. (1965). Infection with influenza and parainfluenza viruses in chronic bronchitis. Thorax, 20, 124.

Stenhouse, A. C. (1967). Rhinovirus infection in acute exacerbations of chronic bronchitis: a controlled prospective study. Brit. med. J., 3, 461 .

Stott, E. J., Grist, N. R., and Eadie, M. B. (1968). Rhinovirus infections in chronic bronchitis: isolation of eight possibly new rhinovirus serotypes. J. med. Microbiol., 1, 109.

Stuart-Harris, C. H. (1968). Chronic bronchitis. Abstr. Wld Med., 42, 649, 737.

Taylor-Robinson, D., Purcell, R. H., Wong, D. C., and Chanock, R. M. (1966). A colour test for the measurement of antibody to certain mycoplasma species based upon the inhibition of acid production. J. Hyg. (Lond.), $64,91$.

Tully, J. G. (1969). Murine mycoplasmas. In The Mycoplasmatales and the L-phase of Bacteria. Edited by L. Haflick, p. 571. Appleton-Century-Crofts, New York. 